\title{
Paparan iklan televisi terhadap pemilihan makanan dan asupan energi pada anak
}

Influence of exposure to television ads to food choice and energy intake in children

Yovita Puri Subardjo ${ }^{1}$, Toto Sudargo ${ }^{2}$, Madarina Julia ${ }^{3}$

\begin{abstract}
Background: Obesity in school children is the problem of world epidemics of which its prevalence increases sharply. Food marketing through television is presumed to be one of the causing factors. Objective: To find out whether exposure to food and beverage ads through television influenced food choice and intake in children and whether its effect varied in different nutrition status. Method: The study was an experiment involving 2 experiment groups. The first group was exposed to film with food and beverage ads; the second with ads excluding foods and beverages. The children were given 8 advertised foods and drinks and 4 natural foods. Assessment was then made on energy intake and food choice. Population of the study was elementary school children at Yogyakarta Municipality and samples were selected through multi-stage random sampling. Data were analyzed descriptively and through correlation analysis. Results: Children exposed to food and beverage television ads had higher energy intake (262.7 \pm 99.7

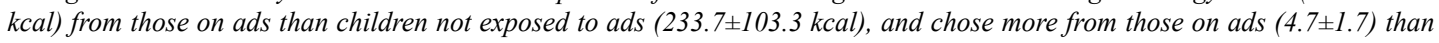
children not exposed to ads (4.2 \pm 1.7$)$. Children with normal nutrition status were influenced more by food and beverage television ads than children with over nourished and undernourished nutrition status. Conclusion: Exposure to food and beverage television ads influenced food choice and energy intake in children.
\end{abstract}

KEYWORDS: television ads, food choice, energy intake

\begin{abstract}
ABSTRAK
Latar belakang: Kegemukan anak usia sekolah merupakan masalah epidemi dunia yang prevalensinya mengalami peningkatan tajam. Pemasaran makanan diantaranya melalui iklan televisi (TV) dimungkinkan sebagai salah satu faktor penyebabnya. Tujuan: Mengetahui apakah paparan iklan makanan dan minuman TV mempengaruhi pemilihan dan asupan makan anak dan apakah efeknya berbeda pada status gizi yang berbeda. Metode: Penelitian eksperimental pada 2 kelompok dengan perlakuan pertama yaitu pemaparan film dengan iklan makanan dan minuman dan perlakuan kedua dengan iklan selain makanan dan minuman. Anak diberikan 8 makanan dan minuman yang diiklankan dan 4 makanan alami kemudian diukur asupan energi dan pemilihan makanannya. Populasi penelitian yaitu anak sekolah dasar di Kota Yogyakarta dengan pengambilan sampel secara multi-stage random sampling. Analisis yang dilakukan adalah analisis data deskriptif dan analisis hubungan dengan menggunakan $t$-test. Hasil: Anak yang terpapar iklan makanan dan minuman TV memiliki asupan energi lebih tinggi dari makanan minuman yang diiklankan $(262,7 \pm 99,7 \mathrm{kkal})$ daripada anak yang tidak terpapar $(233,7 \pm 103,3 \mathrm{kkal})$ dan memilih makanan yang diiklankan lebih banyak $(4,7 \pm 1,7)$ daripada anak yang tidak terpapar $(4,2 \pm 1,7)$. Anak dengan status gizi normal lebih terpengaruh iklan makanan dan minuman TV daripada anak dengan status gizi lebih dan kurang. Simpulan: Paparan iklan makanan dan minuman TV berpengaruh terhadap pemilihan makanan dan asupan energi anak pada makanan dan minuman yang diiklankan.
\end{abstract}

KATA KUNCI: iklan televisi, pemilihan makanan, asupan energi

\section{PENDAHULUAN}

Riset Kesehatan Dasar (Riskesdas) tahun 2010 mencatat anak usia 6-12 tahun yang mengalami kegemukan di Indonesia sebesar 9,2\% dan di Daerah Istimewa Yogyakarta (DIY) sebesar 7,8\% (1). Dinas Kesehatan Provinsi DIY menaruh perhatian khusus pada angka obesitas anak di DIY yang meningkat sebesar 7\% pada tahun 2006-2009 (2). Pemasaran makanan yang ditargetkan pada anak-anak dimungkinkan sebagai faktor penyebab epidemi obesitas (3). Pemasaran makanan mempengaruhi pemilihan makanan anak, konsumsi, kesehatan, obesitas, dan berhubungan dengan iklan

\footnotetext{
Korespondensi: Program Studi Ilmu Gizi, Fakultas Ilmu-ilmu Kesehatan Universitas Jenderal Soedirman, Jl. dr. Soeparno, Karangwangkal, Purwokerto 53123,e-mail: yovitapuri@gmail.com

2 Program Studi Gizi Kesehatan, Fakultas Kedokteran Universitas Gadjah Mada, Jl. Farmako, Sekip Utara, Yogyakarta 55281,e-mail: toto_sudargo@yahoo.co.id

${ }^{3}$ Bagian Ilmu Kesehatan Anak Rumah Sakit Umum Pusat Dr. Sardjito/Fakultas Kedokteran Universitas Gadjah Mada, Jl. Kesehatan No 1 Yogyakarta, e-mail: madarinajulia@yahoo.com
} 
televisi (TV) (4). Anak usia 2-11 tahun melihat TV ratarata $3 \mathrm{jam} /$ hari dan melihat $5.500 \mathrm{iklan} / \operatorname{tahun}(5)$.

Sembilan dari 10 iklan makanan bersifat tinggi lemak, sodium, gula tambahan, atau tidak bergizi (4). Paparan iklan berefek pada asupan dan pemilihan makanan serta berhubungan dengan obesitas anak (6). Anak yang obesitas mengenali iklan makanan TV lebih banyak daripada anak yang memiliki status gizi normal (7). Perbedaan budaya dan pemasaran makanan di Eropa dan Indonesia mendorong penulis untuk melakukan studi serupa dengan metode penelitian yang dimodifikasi dan disesuaikan dengan keadaan di Indonesia. Penelitian ini bertujuan untuk mengetahui pengaruh paparan iklan makanan dan minuman TV terhadap pemilihan makanan dan asupan energi anak serta perbedaannya pada status gizi yang berbeda. Selain itu, apakah iklan TV mendorong terbentuknya status gizi lebih khususnya pada anak di Yogyakarta.

\section{BAHAN DAN METODE}

Penelitian ini merupakan penelitian kuantitatif dengan jenis eksperimental dan disain penelitian eksperimental murni karena dilakukan alokasi subjek secara acak ke dalam 2 kelompok yang diberikan 2 paparan iklan berbeda. Penelitian dilaksanakan pada bulan April sampai Mei 2012. Gambaran karakteristik subjek serta karakteristik penggunaan media elektronik, uang jajan, dan konsumsi makanan diketahui dengan menggunakan kuesioner yang dikirimkan kepada orang tua subjek. Data karakteristik subjek terdiri dari umur, jenis kelamin, status gizi, status gizi ibu, status pekerjaan ibu, dan pendapatan keluarga. Status gizi ibu diperoleh dengan recall berat badan dan tinggi badan ibu. Pendapatan keluarga dikategorikan menjadi dua yaitu kurang dari Rp 4.040.000,- dan lebih dari atau sama dengan Rp 4.040.000,-. Nilai pendapatan sebesar Rp 4.040.000,- ditetapkan dengan perhitungan 5 kali upah minimum regional (UMR) DIY tahun 2012 sebesar Rp 808.000,- dikali 5 (asumsi 1 keluarga beranggotakan 5 orang). Data karakteristik penggunaan media elektronik, uang jajan, dan konsumsi makan digali karena memiliki keterkaitan dengan pengaruh paparan iklan TV dan status gizi subjek. Data tersebut terdiri dari penggunaan TV kabel, keberadaan TV di kamar anak, lama menonton $\mathrm{TV}$, lama bermain video game, lama duduk di belakang komputer, uang jajan, konsumsi soft drink, konsumsi fastfood, serta konsumsi sayur dan buah.

Sebelum diberikan perlakuan, semua anak diberikan makanan berupa arem-arem agar anak tidak lapar selama mengikuti eksperimen dan berada dalam kondisi yang kurang lebih sama. Perlakuan kelompok I (terpapar iklan) dengan memberikan pemaparan film yang disisipi iklan makanan. Perlakuan kelompok II (tidak terpapar iklan) dengan memberikan pemaparan film yang disisipi iklan bukan makanan. Setelah perlakuan, anakanak diberikan 1 paket makanan yang sama. Anak-anak dipersilahkan makan sesuka dan sebanyak yang mereka inginkan. Setelah selesai makan, jumlah makanan yang tersisa dicatat untuk dihitung asupan energinya dan jumlah makanan yang dimakan dicatat untuk menentukan jumlah makanan yang dipilih (pemilihan makanan). Makanan yang disajikan kepada setiap anak terdiri dari 1 paket makanan yang berisi 8 makanan yang diiklankan (dipaparkan pada kelompok I) dan 4 makanan alami seperti tercantum dalam Tabel 1.

Populasi penelitian ini adalah seluruh anak sekolah dasar (SD) di Kota Yogyakarta dengan sampel yang diambil secara acak dengan metode multi-stage random sampling dari 182 SD di Kota Yogyakarta (11). Subjek

Tabel 1. Kategori makanan dan minuman yang digunakan dalam penelitian

\begin{tabular}{ll}
\hline \multicolumn{1}{c}{ Makanan yang diiklankan } & \multicolumn{1}{c}{ Makanan alami } \\
\hline Makanan gurih tinggi lemak(6), fast food (8) & Makanan gurih, tidak tinggi lemak \\
Bentuk makanan: sosis so nice, biskuit tuc & Bentuk makanan: sawut \\
\hline Makanan manis dan tinggi lemak(6) & Makanan manis dan tidak tinggi lemak \\
Bentuk makanan: bim-bim biskuit, choky-choky & Bentuk makanan: pisang rebus \\
\hline Makanan rendah gizi (rendah serat dan mikronutrien) (9) & Makanan bergizi (tinggi serat dan mikronutrien) \\
Bentuk makanan: permen yupi, taro & Bentuk makanan: duku \\
\hline Soft drink dan minuman bergula (10) & Minuman tidak bergula \\
Bentuk minuman: ale-ale, teh rio & Bentuk minuman: air putih \\
\hline
\end{tabular}

102 • Jurnal Gizi Klinik Indonesia, Vol. 10, No. 2, Oktober 2013 
penelitian merupakan siswa SD sebanyak 212 anak yang diambil dari 3 SD berbeda, kemudian dimasukkan ke dalam 2 kelompok perlakuan secara acak. Besar sampel dalam penelitian ini dihitung menggunakan software Pass 11 (12) dengan risk ratio gizi lebih akibat paparan iklan makanan dan minuman TV diperoleh dari penelitian sebelumnya sebesar 2,7 (8) dan data prevalensi obesitas di DIY sebesar 7,8\% diperoleh dari data Riskesdas tahun 2010 (13), maka besar sampel minimal untuk studi ini sebanyak 106 subjek setiap kelompok sehingga jumlah total subjek yang dibutuhkan sebesar 212 anak.

Kriteria inklusinya adalah siswa SD berusia 8-12 tahun dan bersedia mengikuti penelitian dengan persetujuan dari orang tua melalui informed concent. Kriteria eksklusinya adalah tidak menyelesaikan tahapan perlakuan hingga selesai dan memiliki alergi atau pantangan terhadap makanan yang digunakan dalam penelitian. Penetapan usia anak 8-12 tahun sesuai dengan tahapan perkembangan anak usia tersebut yaitu the concrete operational stage. Pada tahapan ini sifat intuitif, bipolar, pemikiran egois telah mulai bergeser pada sifat logis, pemikiran rasional, dan pembedaan pada rasa dan pemilihan serta dapat berpikir benar dan salah tentang apa yang dikatakan orang tua, media, dan tokoh (14). Variabel penelitian meliputi variabel terikat (asupan makanan dan pemilihan makanan) dan variabel bebas (paparan iklan makanan dan minuman TV). Penelitian ini juga memasukkan status gizi sebagai efek modifikasi.

Asupan makanan adalah total energi yang dikonsumsi anak dari makanan dan minuman yang dihidangkan setelah paparan iklan. Sisa makanan dicatat jumlahnya sebagai dasar untuk menghitung jumlah makanan yang dimakan dan energi yang diasup. Pemilihan makanan dinyatakan dalam jumlah makanan dipilih setelah paparan iklan. Makanan pilihan terdiri dari makanan yang diiklankan ( 8 jenis) dan makanan alami yang tidak diiklankan (4 jenis). Pemilihan makanan dihitung dari jumlah makanan yang diiklankan atau makanan alami yang dipilih. Pemilihan makanan total dihitung dari jumlah keduanya.

Paparan iklan pada grup pertama adalah penayangan iklan makanan dan minuman selama pemutaran film kepada anak. Jumlah iklan sebanyak 30 iklan makanan dan minuman yang disisipkan di antara 3 seri film kartun yang ditayangkan. Setiap iklan memiliki durasi tayang sekitar 30 detik. Paparan iklan pada grup kedua adalah penayangan iklan non makanan dan minuman selama pemutaran film kepada anak. Jumlah iklan sebanyak 30 iklan bukan makanan dan minuman yang disisipkan di antara 3 seri film kartun yang ditayangkan. Setiap iklan memiliki durasi tayang sekitar 30 detik.

Status gizi dalam penelitian ini diketahui dengan menggunakan indeks massa tubuh (IMT) yang diperoleh dari pengukuran berat badan $(\mathrm{kg})$, tinggi badan $(\mathrm{cm})$, dan umur (bulan). Berat badan diperoleh dengan menimbang anak menggunakan timbangan digital. Sebelum ditimbang, barang-barang seperti handphone, sabuk, dan barang lain yang dibawa diletakkan terlebih dahulu. Tinggi badan diperoleh dengan melakukan pengukuran tinggi badan anak dalam keadaan tegak tanpa alas kaki menggunakan mikrotois yang terpasang di dinding yang rata. Data berat badan, tinggi badan, dan umur tersebut digunakan sebagai data untuk menentukan IMT per umur (IMT/U) sesuai dengan Growth Reference Data for 5-19 Years, World Health Organization (WHO) 2007. Perhitungan IMT per umur (IMT/U) pada penelitian ini dilakukan dengan menggunakan Stata 11 dan Stata Macro. Indeks massa tubuh per umur (IMT/U) dalam $z$-score dikategorikan ke dalam 4 kategori status gizi yaitu: kurus jika $z$-score $<-2$, normal jika $z$-score $\geq-2$ dan $\leq 1$, kelebihan gizi (overweight) jika $z$-score $>1$ dan $<2$, dan obes jika $z$-score $\geq 2$.

Setelah proses pengambilan, pengelompokkan, pembersihan, dan pengkodean data, peneliti memperoleh data yang siap dianalisis. Proses selanjutnya adalah analisis data deskriptif dan analisis hubungan antarvariabel. Dianalisis pula perbedaan karakteristik subjek pada kedua kelompok untuk mengetahui apakah kedua kelompok memiliki kesamaan karakter untuk dapat dibandingkan. Analisis bivariat dilakukan untuk menganalisis hubungan antara dua variabel. Data asupan energi dan pemilihan makanan dianalisis dengan $t$-test yaitu analisis beda ratarata asupan energi dan pemilihan makanan pada masingmasing anak dalam kedua kelompok yang status gizinya sama. Penelitian dilaksanakan setelah peneliti mendapatkan surat kelaikan etik penelitian dari Komite Etik Penelitian Biomedis pada Manusia Fakultas Kedokteran Universitas Gadjah Mada. 
HASIL

\section{Karakteristik subjek penelitian}

Dari uji homogenitas diketahui bahwa tidak terdapat perbedaan umur, jenis kelamin, status gizi, status gizi ibu, status pekerjaan ibu, dan pendapatan keluarga pada kedua kelompok (Tabel 2). Keberadaan media seperti TV, video game, dan komputer merupakan faktor lingkungan yang penting dalam studi kegemukan pada anak yang dilakukan di berbagai negara. Uji homogenitas dilakukan terhadap keberadaan TV kabel di rumah, tersedianya TV di kamar anak, lama menonton TV, lama bermain video game, dan lama duduk menggunakan komputer, hasilnya menunjukkan bahwa tidak ada perbedaan pada kedua kelompok perlakuan. Demikian juga, tidak terdapat perbedaan $(\mathrm{p}<0,05)$ uang jajan, konsumsi soft drink, fast food, sayur, dan buah pada kedua kelompok (Tabel 3).

\section{Asupan energi dan pemilihan makanan setelah paparan iklan}

Terdapat perbedaan asupan energi dari makanan yang diiklankan pada kelompok terpapar iklan dan tidak terpapar $(p<0,05)$. Anak dengan status gizi normal pada kelompok terpapar iklan makanan TV, memiliki asupan energi lebih besar daripada anak dengan status gizi normal pada kelompok tidak terpapar $(\mathrm{p}<0,05)$ (Tabel 4). Terdapat perbedaan pemilihan makanan yang diiklankan dan jumlah total pemilihan makanan antara kelompok terpapar iklan makanan TV dan tidak terpapar $(\mathrm{p}<0,05)$. Kelompok terpapar iklan makanan TV memilih lebih banyak makanan yang diiklankan dan jumlah total pemilihan makanan lebih tinggi daripada kelompok yang tidak terpapar iklan makanan TV. Anak dengan status gizi normal pada kelompok terpapar iklan makanan TV memilih lebih banyak makanan yang diiklankan dibandingkan dengan anak dengan status gizi normal pada kelompok yang tidak dipaparkan iklan makanan TV $(p<0,05)$ seperti terdapat dalam Tabel 5.

Standar deviasi (SD) dari data asupan energi tergolong besar terutama pada data asupan energi dari makanan alami. Hal ini menunjukkan variasi asupan energi yang lebar dari tiap-tiap subjek. Variasi yang lebar merupakan koreksi terhadap metode pengambilan data. Hal ini kemungkinan karena waktu eksperimen setiap serinya (1 seri terdiri dari 1 percobaan untuk kelompok terpapar iklan makanan dan 1 percobaan untuk kelompok tidak terpapar iklan makanan) yang tidak sama bergantung pada wali kelas yang menentukan jadwal penelitian berdasarkan jam pelajaran yang

Tabel 2. Karakteristik subjek

\begin{tabular}{|c|c|c|c|c|}
\hline Variabel & Kelompok terpapar iklan & Kelompok tidak terpapar iklan & $\chi^{2}$ & $\mathbf{p}$ \\
\hline & n (\%) & n (\%) & & \\
\hline Umur (tahun), rerata (SD) & $10,14(0,79)$ & $10,16(0,98)$ & - & 0,89 \\
\hline Jenis kelamin & & & 1,21 & 0,27 \\
\hline Perempuan & $48(45,30)$ & $56(52,80)$ & & \\
\hline Laki-laki & $58(54,70)$ & $50(47,20)$ & & \\
\hline Status gizi & & & 4,02 & 0,26 \\
\hline Kurus & $11(10,40)$ & $13(12,20)$ & & \\
\hline Normal & $37(34,90)$ & $45(42,40)$ & & \\
\hline Overweight & $30(28,30)$ & $18(17,00)$ & & \\
\hline Obesitas & $28(26,40)$ & $30(28,30)$ & & \\
\hline Status gizi ibu & & & 0,47 & 0,49 \\
\hline Kurus-normal & $51(48,11)$ & $56(52,83)$ & & \\
\hline Gizi lebih & $55(51,89)$ & $50(47,17)$ & & \\
\hline Status pekerjaan ibu & & & 0,02 & 0,89 \\
\hline Bekerja & $57(53,77)$ & $56(52,83)$ & & \\
\hline Tidak & $49(46,23)$ & $50(47,17)$ & & \\
\hline Pendapatan keluarga (rupiah) & & & 0,02 & 0,88 \\
\hline$<4.040 .000$ & $70(66,04)$ & $71(66,98)$ & & \\
\hline$\geq 4.040 .000$ & $36(33,96)$ & $35(33,02)$ & & \\
\hline
\end{tabular}


Yovita Puri Subardjo, dkk: Paparan iklan televisi terhadap pemilihan makanan dan asupan energi pada anak

Tabel 3. Karakteristik penggunaan media elektronik, uang jajan, dan konsumsi

\begin{tabular}{|c|c|c|c|c|}
\hline \multirow[t]{2}{*}{ Variabel } & $\begin{array}{c}\begin{array}{c}\text { Kelompok terpapar } \\
\text { iklan }\end{array} \\
\end{array}$ & $\begin{array}{c}\text { Kelompok tidak } \\
\text { terpapar iklan }\end{array}$ & \multirow[t]{2}{*}{$\chi^{2}$} & \multirow[t]{2}{*}{$\mathbf{p}$} \\
\hline & & n (\%) & & \\
\hline TV kabel & & & 1,33 & 0,25 \\
\hline Ya & $41(38,70)$ & $33(31,10)$ & & \\
\hline Tidak & $65(61,30)$ & $73(68,90)$ & & \\
\hline TV di kamar anak & & & 1,62 & 0,20 \\
\hline Ya & $45(42,40)$ & $61(57,60)$ & & \\
\hline Tidak & $36(34,00)$ & $70(66,00)$ & & \\
\hline Lama menonton TV hari sekolah (jam), mean (SD) & $3,3(1,60)$ & $3,04(1,80)$ & & 0,24 \\
\hline Lama menonton TV weekend (jam), mean (SD) & $4,8(2,30)$ & $4,6(2,20)$ & & 0,58 \\
\hline Lama bermain video game (jam), mean (SD) & $1,3(1,10)$ & $1,05(0,90)$ & & 0,08 \\
\hline Lama duduk di belakang komputer (jam), mean (SD) & $1,05(0,80)$ & $0,95(0,80)$ & & 0,36 \\
\hline Uang jajan (rupiah) & $5330(3195)$ & $4924(2896)$ & & 0,33 \\
\hline Konsumsi softdrink/minggu & & & 7,20 & 0,13 \\
\hline $\mathrm{Ya}$ & $46(43,40)$ & $32(30,19)$ & 3,98 & 0,05 \\
\hline Tidak & $60(56,60)$ & $74(69,81)$ & & \\
\hline Konsumsi fastfood/minggu & & & 0,32 & 0,85 \\
\hline 0 & $28(26,42)$ & $31(29,83)$ & & \\
\hline $1-2$ kali & $57(53,77)$ & $53(50,00)$ & & \\
\hline$>2$ kali & $21(19,81)$ & $22(20,75)$ & & \\
\hline Konsumsi sayur/hari & & & 4,13 & 0,13 \\
\hline $0-1$ porsi & $60(56,60)$ & $53(50,00)$ & & \\
\hline 2 porsi & $30(28,30)$ & $43(40,57)$ & & \\
\hline 3 porsi & $16(15,09)$ & $10(9,43)$ & & \\
\hline Konsumsi buah/hari & & & 1,26 & 0,51 \\
\hline 0 porsi & $17(16,04)$ & $17(16,04)$ & & \\
\hline 1 porsi & $64(60,38)$ & $57(53,77)$ & & \\
\hline $2-3$ porsi & $25(23,58)$ & $32(30,19)$ & & \\
\hline
\end{tabular}

dimungkinkan untuk ditinggalkan oleh subjek penelitian. Waktu penelitian beragam yaitu pagi sebelum istirahat, saat istirahat, setelah istirahat sekolah, dan menjelang waktu pulang sekolah. Hal ini menyebabkan kondisi tingkat kekenyangan subjek yang beragam. Walaupun sebelum eksperimen dimulai, subjek sudah dikondisikan dengan memberikan makanan berupa arem-arem. Namun, diduga subjek di setiap seri eksperimen memiliki kondisi kenyang yang berbeda-beda di awal eksperimen.

\section{BAHASAN}

\section{Karakteristik subjek penelitian}

Prevalensi status gizi lebih pada ketiga SD yang digunakan dalam penelitian ini lebih tinggi dari angka gizi lebih anak di DIY (7,8\%) (1). Prevalensi status gizi lebih pada kelompok I yaitu overweight 28,3\% dan obesitas $26,4 \%$, pada kelompok II yaitu overweight $17 \%$ dan obesitas 28,3\%. Prevalensi status gizi lebih pada penelitian ini mendekati prevalensi status gizi lebih pada anak di Amerika tahun 2008 yaitu overweight 32\% dan obesitas $17 \%$ (15).

Prevalensi subjek yang memiliki TV di kamar masing-masing pada kelompok I sebesar 42,4\% dan kelompok II sebesar 57,6\%. Hal ini sesuai dengan penelitian prevalensi anak yang memiliki TV di kamar sebesar 47\%. Anak-anak yang memiliki TV di kamar, lebih berisiko overweight $(\mathrm{OR}=1,31)$ dan menghabiskan waktu menonton TV lebih banyak (4,6 jam per minggu) daripada anak yang tidak memiliki TV di kamar (15). Subjek penelitian ini melihat TV selama 3 jam pada hari sekolah dan 4 jam pada akhir pekan. Anak-anak pada kelompok I melihat TV rata-rata selama 3 jam 18 menit pada hari sekolah dan 4 jam 48 menit pada akhir pekan 
Tabel 4. Perbedaan asupan energi pada kelompok terpapar iklan dan tidak

\begin{tabular}{|c|c|c|c|c|c|c|c|c|c|}
\hline \multirow[b]{2}{*}{ Variabel } & \multicolumn{3}{|c|}{ Kelompok terpapar iklan } & \multicolumn{3}{|c|}{ Kelompok tidak terpapar iklan } & \multirow[b]{2}{*}{$\begin{array}{c}\text { Mean } \\
\text { Diff }\end{array}$} & \multirow[b]{2}{*}{$95 \%$ CI } & \multirow[b]{2}{*}{$\mathbf{p}$} \\
\hline & $\mathbf{n}$ & $\begin{array}{c}\text { Rerata energi } \\
\text { (kkal) }\end{array}$ & SD & $\mathbf{n}$ & $\begin{array}{l}\text { Rerata energi } \\
\text { (kkal) }\end{array}$ & SD & & & \\
\hline Energi dari makanan iklan & 106 & 262,70 & 99,70 & 106 & 233,70 & 103,30 & 29 & $1,54-56,52$ & 0,04 \\
\hline Energi dari makanan alami & 106 & 43,40 & 52,70 & 106 & 51,60 & 62,00 & $-8,20$ & $-23,79-7,36$ & 0,29 \\
\hline Energi total & 106 & 306,10 & 106,80 & 106 & 285,20 & 113,70 & 20,90 & $-9,06-50,68$ & 0,17 \\
\hline \multicolumn{10}{|l|}{$\begin{array}{l}\text { Energi dari makanan iklan } \\
\text { pada setiap status gizi }\end{array}$} \\
\hline Kurus & 11 & 234,90 & 112,22 & 13 & 211,92 & 53,70 & 22,98 & $-49,58-95,55$ & 0,52 \\
\hline Normal & 37 & 284,41 & 101,79 & 45 & 230,38 & 100,30 & 54,03 & $9,44-98,62$ & 0,02 \\
\hline Overweight & 30 & 251,17 & 70,73 & 18 & 209,06 & 101,40 & 42,11 & $-7,94-92,17$ & 0,09 \\
\hline Obesitas & 28 & 257,21 & 116,83 & 30 & 262,73 & 121,30 & $-5,52$ & $-68,24-57,20$ & 0,86 \\
\hline \multicolumn{10}{|l|}{$\begin{array}{l}\text { Energi dari makanan alami } \\
\text { pada setiap status gizi }\end{array}$} \\
\hline Kurus & 11 & 40,72 & 49,72 & 13 & 35,00 & 47,98 & 5,72 & $-0,35-47,17$ & 0,78 \\
\hline Normal & 37 & 32,67 & 45,18 & 45 & 54,58 & 71,10 & $-21,91$ & $-48,76-4,96$ & 0,10 \\
\hline Overweight & 30 & 44,40 & 52,04 & 18 & 46,22 & 45,89 & $-1,82$ & $-31,74-28,09$ & 0,90 \\
\hline Obesitas & 28 & 57,46 & 62,49 & 30 & 57,53 & 62,07 & $-0,07$ & $-32,85-32,71$ & 0,99 \\
\hline \multicolumn{10}{|l|}{$\begin{array}{l}\text { Energi total pada setiap } \\
\text { status gizi }\end{array}$} \\
\hline Kurus & 11 & 275,60 & 124,70 & 13 & 246,90 & 68,60 & 28,70 & $-54,69-112,11$ & 0,48 \\
\hline Normal & 37 & 317,10 & 121,50 & 45 & 285,00 & 126,80 & 32,10 & $-22,83-87,08$ & 0,24 \\
\hline Overweight & 30 & 295,60 & 78,70 & 18 & 255,30 & 82,70 & 40,30 & $-7,84-88,42$ & 0,09 \\
\hline Obesitas & 28 & 314,70 & 107,20 & 30 & 320,30 & 118,40 & $-5,60$ & $-65,12-53,95$ & 0,85 \\
\hline
\end{tabular}

Tabel 5. Perbedaan pemilihan makanan pada kelompok terpapar iklan dan tidak

\begin{tabular}{|c|c|c|c|c|c|c|c|c|c|}
\hline \multirow[b]{2}{*}{ Variabel } & \multicolumn{3}{|c|}{ Kelompok terpapar iklan } & \multicolumn{3}{|c|}{ Kelompok tidak terpapar iklan } & \multirow{2}{*}{$\begin{array}{c}\text { Mean } \\
\text { Diff }\end{array}$} & \multirow[b]{2}{*}{$95 \%$ CI } & \multirow[b]{2}{*}{$\mathbf{p}$} \\
\hline & $\mathbf{n}$ & $\begin{array}{c}\text { Rerata jumlah } \\
\text { makanan dipilih }\end{array}$ & SD & $\mathbf{n}$ & $\begin{array}{c}\text { Rerata jumlah } \\
\text { makanan dipilih }\end{array}$ & SD & & & \\
\hline Pemilihan makanan iklan & 106 & 4,7 & 1,7 & 106 & 4,2 & 1,7 & 0,5 & $0,03-0,93$ & 0,04 \\
\hline Pemilihan makanan alami & 106 & 1,2 & 1,0 & 106 & 1,1 & 1,0 & 0,1 & $-0,17-0,44$ & 0,25 \\
\hline Pemilihan makanan total & 106 & 6,0 & 1,8 & 106 & 5,3 & 1,9 & 0,7 & $0,13-1,15$ & 0,01 \\
\hline \multicolumn{10}{|l|}{$\begin{array}{l}\text { Pemilihan makanan iklan } \\
\text { pada setiap status gizi }\end{array}$} \\
\hline Kurus & 11 & 4,2 & 1,7 & 13 & 4,2 & 1,4 & 0 & $-1,35-1,25$ & 0,94 \\
\hline Normal & 37 & 5,1 & 1,6 & 45 & 4,3 & 1,6 & 0,8 & $0,15-1,59$ & 0,02 \\
\hline Overweight & 30 & 4,9 & 1,3 & 11 & 4,3 & 1,6 & 0,6 & $-0,48-1,49$ & 0,31 \\
\hline Obesitas & 28 & 4,4 & 2,0 & 30 & 4,4 & 1,9 & 0 & $-1,09-1,01$ & 0,94 \\
\hline \multicolumn{10}{|l|}{$\begin{array}{l}\text { Pemilihan makanan alami } \\
\text { pada setiap status gizi }\end{array}$} \\
\hline Kurus & 11 & 1,3 & 1,1 & 13 & 0,8 & 0,9 & 0,5 & $-0,46-1,31$ & 0,33 \\
\hline Normal & 37 & 0,9 & 0,8 & 45 & 1,0 & 0,9 & $-0,1$ & $-0,47-0,31$ & 0,68 \\
\hline Overweight & 30 & 1,4 & 0,9 & 11 & 1,3 & 1,2 & 0,1 & $-0,52-0,77$ & 0,70 \\
\hline Obesitas & 28 & 1,5 & 1,3 & 30 & 1,1 & 0,9 & 0,4 & $-0,19-0,99$ & 0,18 \\
\hline \multicolumn{10}{|l|}{$\begin{array}{l}\text { Pemilihan makanan total } \\
\text { pada setiap status gizi }\end{array}$} \\
\hline Kurus & 11 & 5,5 & 2,0 & 13 & 5,1 & 1,6 & 0,4 & $-1,16-1,91$ & 0,61 \\
\hline Normal & 37 & 6,1 & 2,0 & 45 & 5,3 & 1,9 & 0,8 & $-0,78-1,65$ & 0,07 \\
\hline Overweight & 30 & 6,3 & 1,4 & 11 & 5,7 & 0,9 & 0,6 & $-0,39-1,47$ & 0,25 \\
\hline Obesitas & 28 & 5,9 & 1,9 & 30 & 5,5 & 2,4 & 0,4 & $-0,81-1,53$ & 0,54 \\
\hline
\end{tabular}

106 • Jurnal Gizi Klinik Indonesia, Vol. 10, No. 2, Oktober 2013 
sedangkan kelompok II selama 3 jam 2 menit pada hari sekolah dan 4 jam 36 menit pada akhir pekan. Hal ini lebih tinggi dari rerata anak Australia melihat TV yaitu 2-3 jam per hari (16) dan melebihi standar yang diterapkan di China yaitu melihat TV lebih dari 1,5 jam per hari (17). Anak usia 2-11 tahun menonton TV dengan durasi ratarata 3 jam per hari dan melihat iklan makanan sebanyak 5.500 iklan per tahun (5). Lebih lanjut, diketahui bahwa pada kelompok I rata-rata uang jajan sebesar Rp 5.330,dan pada kelompok II rata-rata sebesar Rp 4.924,-. Sebagian besar anak dalam penelitian ini mengonsumsi fast food setidaknya 1 kali per minggu. Hal ini sejalan dengan penelitian yang dilakukan di New Zealand yang menyimpulkan bahwa anak yang melihat TV 2 jam lebih per hari akan mengonsumsi hamburger dan juga french fries paling tidak 1 kali seminggu (18).

Peningkatan tajam prevalensi anak gizi lebih di Yogyakarta dapat disebabkan oleh beberapa kemungkinan. Faktor lingkungan yang obesogenis (memicu obesitas) yang ditemukan di lapangan adalah mudahnya akses di sekitar sekolah terhadap makanan tinggi energi seperti fast food dan softdrink; makanan dan minuman yang diiklankan di TV dapat dengan mudah ditemukan di kantin sekolah; uang saku yang cukup besar yaitu ratarata $\mathrm{Rp} 5.000$,- cukup digunakan untuk membeli berbagai macam makanan dan minuman yang tinggi energi serta rendah zat gizi yang tersedia di kantin sekolah ataupun penjaja makanan di lingkungan luar sekolah; rendahnya konsumsi sayuran pada sebagian besar anak yaitu hanya mengonsumsi sayuran 0-1 porsi per hari. Di samping itu, kurangnya aktivitas fisik pada anak-anak dapat memicu munculnya status gizi lebih. Tersedia TV di kamar pada kurang lebih 40\% anak dengan waktu melihat TV rata-rata 3 jam/hari. Keberadaan TV di kamar dan lamanya melihat TV mengurangi waktu anak untuk melakukan aktivitas fisik seperti berolahraga atau bermain di luar rumah (19). Selain itu, transportasi modern, lahan bermain di sekolah terbatas, dan sekolah berbatasan langsung dengan jalan raya dapat membatasi aktivitas anak.

Peningkatan jumlah anak dengan status gizi lebih ini merupakan hal yang dikhawatirkan WHO yang menyatakan bahwa prevalensi overweight dan obesitas meningkat tajam pada beberapa tahun ini (20). Perubahan ekonomi makanan dunia berkontribusi terhadap perubahan pola konsumsi seperti makanan tinggi energi dan lemak, khususnya lemak jenuh dan rendah karbohidrat kompleks. Pola makan ini dikombinasi dengan menurunnya pengeluaran energi yang diasosiasikan dengan pola hidup santai seperti penggunaan transportasi bermotor, alat rumah tangga yang praktis, dan waktu santai yang menggantikan waktu untuk beraktivitas fisik (3). Faktor lingkungan yang menyebabkan rendahnya aktivitas fisik dan kecenderungan peningkatan asupan energi seperti keberadaan TV di kamar anak dan tingginya screen time seperti melihat TV, bermain video game, komputer, atau internet perlu disiasati dengan cara peningkatan aktivitas fisik di luar rumah dan kegiatan olah raga.

\section{Asupan energi setelah paparan iklan}

Kelompok dengan pemberian paparan iklan makanan dan minuman di TV memiliki asupan energi dari makanan yang diiklankan lebih tinggi dibandingkan anak tanpa pemberian paparan. Dalam penelitian ini, iklan memberikan dampak bagi peningkatan asupan energi yang mungkin disebabkan oleh berbagai faktor. Anak dengan paparan iklan TV tertarik dengan makanan yang diiklankan karena memuat kesenangan, rasa yang enak, fantasi, keunggulan zat gizi, dan lainnya. Anak mengingat produk makanan dan pesan yang terkandung dalam iklan dan kemudian tertarik untuk memakannya. Ketika makanan disajikan, anak menemukan makanan yang sama dengan yang diiklankan dan pesan yang disampaikan dalam iklan tersebut sehingga anak tertarik untuk memakannya.

Walaupun peningkatan jumlah energi pada kelompok terpapar iklan tidak banyak yaitu 29 kkal, tetapi paparan iklan menimbulkan perubahan asupan energi secara signifikan dibandingkan anak yang tidak diberi paparan iklan TV $(\mathrm{p}=0,04)$. Selisih peningkatan yang tidak banyak ini kemungkinan karena anak pada kelompok yang tidak diberikan perlakuan paparan iklan juga telah melihat iklan tersebut sebelumnya di TV ketika di rumah sehingga mereka pun telah mengingat beberapa produk yang disajikan. Hal ini dapat disimpulkan dari data karakteristik subjek yaitu lama menonton TV pada hari sekolah dan weekend pada kelompok tidak terpapar iklan makanan yaitu 3,04 jam/hari dan 4,6 jam/ hari. Namun, anak yang dipaparkan iklan makanan TV 
cenderung memiliki peningkatan jumlah asupan energi lebih besar dari makanan yang diiklankan. Hal ini menunjukkan bahwa iklan TV menimbulkan stimulus untuk makan lebih banyak dan mempengaruhi asupan energi dalam jangka pendek.

Hasil penelitian ini sejalan dengan penelitian sebelumnya yang mendapatkan hasil bahwa anak yang melihat kartun yang memuat iklan makanan, mengonsumsi snack $45 \%$ lebih banyak daripada anak yang menonton kartun tanpa iklan makanan (21) sedangkan pada penelitian ini peningkatan sebanyak $12 \%$. Perbedaan persentase tersebut disebabkan oleh makanan pada penelitian ini disajikan sesudah pemutaran film sedangkan pada penelitian tersebut pada saat film diputar. Jika makanan dihidangkan pada saat penayangan film, stimulus yang ditimbulkan bersifat real time sedangkan pada penelitian ini stimulus bersifat jangka pendek namun tidak real time. Pemasaran makanan melalui iklan makanan TV menggunakan berbagai macam teknik persuasif seperti penggunaan karakter tertentu yang promotif dan penawaran menarik. Penggunaan karakter tertentu seperti kartun dan karakter yang berbicara meningkatkan pengenalan anak dan menimbulkan sikap positif terhadap produk iklan (22).

Anak dengan status gizi normal pada kelompok terpapar iklan makanan TV memiliki asupan energi lebih besar daripada anak dengan status gizi normal pada kelompok tidak terpapar. Hal tersebut kemungkinan disebabkan oleh beberapa faktor. Faktor pertama yaitu kemungkinan anak dengan status gizi normal memiliki pembatasan makanan di rumah mereka sehingga iklan makanan dan minuman TV lebih menarik dibandingkan anak dengan status gizi lebih yang mungkin tidak dibatasi makanannya di rumah. Faktor kedua yaitu bintang iklan makanan dan minuman TV kebanyakan memiliki postur tubuh yang normal sehingga menimbulkan citra bahwa anak yang memakan makanan yang diiklankan tersebut tidak akan gemuk. Faktor ketiga yaitu anak dengan status gizi normal mungkin masih memiliki kebebasan menyantap makanan sebanyak yang mereka mau karena melihat dirinya tidak gemuk. Anak dengan status gizi normal lebih mudah menerima dan terpengaruh iklan makanan dan minuman TV yang kurang sehat (23). Anak overweight yang terpapar iklan memiliki asupan energi lebih banyak daripada anak dengan status gizi sama tetapi tidak terpapar iklan walaupun tidak signifikan namun jumlah perbedaannya cukup banyak. Anak overweight kemungkinan masih memiliki kebebasan untuk mengonsumsi makanan yang diiklankan karena merasa aman dengan badannya yang tidak terlalu gemuk.

\section{Pemilihan makanan setelah paparan iklan}

Kelompok dengan pemberian paparan iklan makanan dan minuman TV lebih banyak memilih makanan yang diiklankan dari keseluruhan makanan daripada anak yang tidak terpapar. Anak belajar mengenai informasi yang disajikan dalam iklan makanan dan minuman TV tersebut kemudian mempercayai produk yang diklaim dalam iklan tersebut. Iklan menyampaikan bahwa makanan dan minuman tersebut menarik dan memiliki keunggulan seperti sehat, bergizi, enak, dan alami. Pesan dalam iklan dikemas apik dengan menampilkan artis, tokoh kartun, atau olahragawan sebagai bintang iklannya. Penyampaian pesan dalam iklan dibalut dengan menampilkan adegan yang menyenangkan, penuh fantasi, dan petualangan yang sangat menarik bagi anak. Iklan dibalut dengan suasana yang menyenangkan yaitu berhubungan dengan kesenangan dan kebahagiaan, aksi, rasa, hadiah, keinginan, zat gizi, misteri, serta kenyamanan dalam mengonsumsi produk (24).

Anak mendapatkan gambaran inference mengenai keunggulan produk dan mempengaruhi keputusan untuk membeli makanan yang diiklankan tersebut. Pada jangka pendek, paparan iklan makanan dan minuman TV secara signifikan meningkatkan preferensi terhadap makanan yang diiklankan. Hal ini sejalan dengan pernyataan bahwa teknik persuasi sering digunakan untuk mengiklankan makanan selingan pada anak, untuk mempromosikan pengenalan merek, dan preferensi pada makanan yang diiklankan (22). Pemilihan makanan yang condong pada produk-produk makanan yang diiklankan didukung dengan uang saku yang cukup dan akses yang mudah untuk mendapatkan makanan tersebut.

Anak dengan status gizi normal pada kelompok terpapar iklan makanan TV memilih lebih banyak makanan yang diiklankan dibandingkan anak dengan status gizi normal pada kelompok yang tidak terpapar 
iklan makanan TV. Hal ini sesuai dengan penelitian sebelumnya yang menyatakan bahwa anak dengan status gizi normal memilih lebih banyak makanan yang diiklankan dibandingkan dengan anak yang tidak terpapar. Setelah terpapar iklan makanan dan minuman, anak dengan status gizi normal mengekspresikan preferensi lebih besar terhadap makanan yang diiklankan seperti yang terjadi pada anak dengan status gizi lebih. Paparan iklan makanan dan minuman ini mungkin menimbulkan preferensi sementara terhadap makanan obesogenis, tetapi berapa lama preferensi tersebut bertahan belum diketahui (25).

\section{SIMPULAN DAN SARAN}

Paparan iklan TV pada anak-anak meningkatkan asupan energi dan pemilihan makanan dari makanan dan minuman yang diiklankan. Anak dengan status gizi normal yang terpapar iklan makanan dan minuman dari TV memiliki asupan energi dan pemilihan makanan yang diiklankan lebih banyak dibandingkan anak dengan status gizi normal yang tidak terpapar.

Gambaran yang lebih luas mengenai peran pemasaran makanan dan minuman komersial serta media elektronik terhadap peningkatan asupan energi, pemilihan makanan, dan peningkatan prevalensi gizi lebih pada anak, perlu diketahui dengan mengembangkan penelitian lain mengenai akses makanan dan minuman komersial tinggi energi dan perilaku obesogenis seperti perilaku menggunakan media elektronik (TV, video game, internet, komputer maupun handphone). Peran keluarga diperlukan dalam memediasi sikap dan permintaan anak terhadap iklan makanan dan minuman. Selain itu, sekolah hendaknya mengimbangi jenis jajanan di kantin sekolah dengan jenis makanan dan minuman alami yang menyehatkan.

\section{RUJUKAN}

1. Badan Penelitian dan Pengembangan Kesehatan Kementerian Kesehatan RI. Riset kesehatan dasar (Riskesdas 2007). Jakarta: Kemenkes RI; 2007.

2. Kepala Dinas Kesehatan DIY. Keputusan Kepala Dinas Kesehatan Provinsi Daerah Istimewa Yogyakarta Nomor:050/1687/I.3 tentang Rencana Strategis Dinas Kesehatan Provinsi DIY Tahun 2009 - 2013. DIY: Dinas Kesehatan DIY; 2009.
3. WHO. Report of a joint WHO/FAO expert consultation: diet, nutrition and the prevention of chronic diseases. Geneva: World Health Organization; 2003.

4. Batada A, Seitz M, Wootan M, Story M. Perspectives in practice: nine out of 10 food advertisements shown during saturday morning children's television programming are for foods high in fat, sodium, or added sugars, or low in nutrients. J Am Diet Assoc 2008;108(4):673-8.

5. Holt D, Ippolito P, Desrochers D, Kelley C. Children's exposure to TV advertising in 1977 and 2004: information for the obesity debate. Federal Trade Commission. Bureau of Economics Staff Report. Washington, DC: Federal Trade Commission; 2007.

6. Halford JC, Boyland EJ, Hughes G, Oliveira LP, Dovey TM. Beyond-brand effect of television (TV) food advertisements/commercials on caloric intake and food choice of 5-7-year-old children. Appetite 2007;49(1):263-7.

7. Halford JC, Gillespie J, Brown V, Pontin EE, Dovey TM. Effect of television advertisements for foods on food consumption in children. Appetite 2004;42(2):221-5.

8. Chou S, Rashad I, Grossman M. Fast-food restaurant advertising on television and its influence on childhood obesity. Paper presented at Fifth World Congress of the International Health Economics Association; 2006 Des; Barcelona, Spain.

9. Filipovic-Hadziomeragic F, Vilic-Svraka A, Mulaomerovic M. Dietary habits of school children in the FBiH related to the consumption of energy dense, nutrient poor foods and need to control their marketing aimed at children. Mater Sociomed 2009;21(4):192-6.

10. Dixon HG, Scully ML, Wakefield MA, White VM, Crawford DA. The effects of television advertisements for junk food versus nutritious food on children's food attitudes and preferences. Soc Sci Med 2007;65(7):1311-23.

11. Dinas Pendidikan, Pemuda dan Olahraga Provinsi DIY (Dikpora). Daftar nama dan alamat sekolah. [series online] 2012 [cited 2012 Feb 27]. Available from: URL: http.//www. pendidikan-diy.go.id/file/alamat_sekolah/sd_yogyakarta.xls

12. Hintze J. PASS 11. [series online] 2011 [cited $2012 \mathrm{Mar}$ 6]. Available from: URL: http.//www.ncss.com

13. Badan Penelitian dan Pengembangan Kesehatan Kementerian Kesehatan RI. Riset kesehatan dasar (Riskesdas 2010). Jakarta: Kemenkes RI; 2010.

14. Moore E, Lutz R. Children, advertising, and product experiences: a multimethod inquiry. Journal of Consumer Research 2000;27(1):31-48.

15. Hingle M, Kunkel D. Childhood obesity and the media. Pediatr Clin North Am 2012;59(3):677-92.

16. Neville L, Thomas M, Bauman A. Food advertising on Australian television: the extent of children's exposure. Health Promot Int 2005;20(2):105-12. 
17. Wang N, Xu F, Zheng LQ, Zhang XG, Li Y, Sun GZ, Guo XF, Yu SS, Sun YX. Brief report children and adolescents: effects of television viewing on body fatness among Chinese children and adolescents. Chin Med J 2012;125(8):1500-3.

18. Utter J, Scragg R, Schaaf D. Associations between television viewing and consumption of commonly advertised foods among New Zealand children and young adolescents. Public Health Nutr 2005;9(5):606-12.

19. McKetta S, Rich M. The fault, dear viewer, lies not in the screens, but in ourselves: relationships between screen media and childhood overweight/obesity. Pediatr Clin North Am 2011;58(6):1493-508.

20. WHO. Global status report on noncommuncable disease. [series online] 2010 [cited 2012 Jan 3]. Available from: URL: http:.// www.who.int $/ \mathrm{nmh} /$ publications/ncd_report_full_en.pdf

21. Harris JL, Bargh JA, Brownell KD. Priming effects of television food advertising on eating behavior. Health Psychol 2009;28(4):404-13.
22. Kelly B, Hattersley L, King L, Flood V. Persuasive food marketing to children: use of cartoons and competitions in Australian commercial television advertisements. Health Promot Int 2008;23(4):33744.

23. Adachi-Mejia AM, Sutherland LA, Longacre MR, Beach ML, Titus-Ernstoff L, Gibson JJ, Dalton MA. Adolescent weight status and receptivity to food TV advertisements. J Nutr Educ Behav 2011;43(6):441-8.

24. Connor SM. Food-related advertising on preschool television: building brand recognition in young viewers. Pediatrics 2006;118(4):1478-85.

25. Halford JC, Boyland EJ, Cooper GD, Dovey TM, Smith CJ, Williams N, Lawton CL, Blundell JE. Children's food preferences: effects of weight status, food type, branding and television food advertisements (commercials). Int J Pediatr Obes 2008;3(1):31-8. 